\title{
Energy saving potential of semi-transparent photovoltaic elements for building integration
}

\author{
L. Olivieri ，E. Caamaño-Martín ，F.J. Moralejo-Vázquez ，N. Martín-Chivelet ， \\ F. Olivieri , F.J. Neila-Gonzalez
}

\begin{abstract}
A B S T R A C T
Within the building energy saving strategies, BIPV (building integrated photovoltaic systems) present a promising potential based on the close relationship existing between these multifunctional systems and the overall building energy balance. Building integration of STPV (semi-transparent photovoltaic) elements affects deeply the building energy demand since it influences the heating, cooling and lighting loads as well as the local electricity generation. This work analyses over different window-to-wall ratios the overall energy performance of five STPV elements, each element having a specific degree of transparency, in order to assess the energy saving potential compared to a conventional solar control glass compliant with the local technical standard. The prior optical characterization, focused to measure the spectral properties of the elements, was experimentally undertaken. The obtained data were used to perform simulations based on a reference office building using a package of specific software tools (DesignBuilder, EnergyPlus, PVsyst, and COMFEN) to take proper account of the STPV peculiarities. To evaluate the global energy performance of the STPV elements a new Energy Balance Index was formulated. The results show that for intermediate and large façade openings the energy saving potential provided by the STPV solutions ranges between $18 \%$ and $59 \%$ compared to the reference glass.
\end{abstract}

\section{Introduction}

BIPV (building-integrated photovoltaics) is one of the most promising technologies enabling buildings to generate part of their electricity needs while performing one or several architectural functionalities [1-4]. In fact, to minimize the final energy demand of buildings, it is necessary firstly to cut down the energy demand needed to guarantee thermal and lighting comfort and then to cover the residual demand using local efficient energy systems [5-7]. In this sense, due to the important role played by the glazing elements in the building envelope to reduce energy demands in terms of heating, cooling and lighting loads, the relationship between façade design and building energy performance has been widely investigated [8-12]. If, on the one hand, the state-of-art best performing commercial fenestration products and future research opportunities have been extensively studied [3,13-15], on the other hand an innovative and emerging technology consisting of using STPV (semitransparent photovoltaic), transparency provided by separating individual solar cells within the module or by eliminating parts of the solar cells during their manufacturing process) modules integrated in façades has not been appropriately studied yet $[16,17]$.

The lack of knowledge about STPV solutions in terms of global energy performance is particularly emphasized in view of the fact that the active building envelope is required to perform multiple (and sometimes opposed) requirements such as: solar shading in summer to avoid overheating, solar gains and thermal insulation in winter to reduce heat loads, daylighting provision to reduce lighting loads, outside view allowance to the occupants and maximum electrical output supply. Thus, to improve the building overall energy efficiency, the achievement of a balance between these functionalities is required. Nevertheless to date, research on the multifunctional effect of STPV solutions on the building energy balance 
has been limited. Concerning the total building energy demand, Wong et al. [18] presented power generation, thermal balance and daylight models of roof integrated mc-Si (multicrystalline silicon) STPV and incorporated them into EnergyPlus [19] to carry out overall energy consumption analysis in five climate regions in Japan. It was concluded that with appropriate optimization measures (transparent insulation material and opaque movable insulation depending on the climate region) net energy savings in the range of $3.0-8.7 \%$ can be achieved relative to the base case of BIPV roof. Miyazaki et al. [20] expounded the effect of thin-film PV elements transmittance and window-to-wall ratio on the energy consumption of office buildings in terms of heating and cooling loads, daylighting and electricity production. Simulations were carried out using EnergyPlus and the main finding was that the total building electricity consumption could be reduced by $55 \%$ using optimum STPV windows. Khai Ng et al. [21] used the same simulation tool to examine six commercially available STPV elements. They defined a new index to evaluate the overall energy performance in Singapore and found that BIPV glazing solutions provide an energy savings rate of between $16.7 \%$ and $41.3 \%$ compared to common window glazing for large façade openings. He et al. [22] compared experimentally and numerically the performance of a-Si PV double and single glazing windows in east China. They found that the double-glazing solution can reduce to $46 \%$ the indoor heat gains, improving the indoor thermal comfort level. Bahaj et al. [23] compared the impact of electrochromic glazing, holographic optical elements, aerogel glazing and thin film PV elements on two highly glazed buildings in arid Middle Eastern climates using TRNSYS [24]. They concluded that glazing integrated thin-film PV solutions are potentially the most promising solution providing an annual cooling load reduction of $31 \%$. The same software was used by Song et al. [25] to calibrate the experimental power output of a commercial STPV thin-film module modified into a double-glazed one. It was found that the computed data was $8.5 \%$ lower than measured output. An experimental study was performed by Peng et al. [26] in order to assess the thermal performance of a ventilated PV double skin façade in Honk Kong. They studied the variation of the SHGC (solar heat gain coefficient) and $U$-value depending on the operation mode of the façade, defining the optimum strategy to improve its thermal behaviour under different weather conditions. Park et al. [27] experimentally analyzed the thermal and electrical performance of a double glazing mc-Si element. Various types of glass (such as clear, green, blue and bronze) were used as back sheet of the PV laminate mounted in the insulated glazing, finding that the rear glass hardly affects the PV module temperature and consequently its electrical performance. Chen et al. [28] used an indoor setup (calorimeter and solar simulator) to determine the SHGC of five STPV glazing elements. The sensitivity analysis concluded that with an increasing angle of incident solar radiation, the SHGC and power generation are reduced significantly (up to $20 \%$ ) whereas the electrical operation conditions reduce the SHGC by only $3-6 \%$, proportionally to the electrical power output of the element. Lu and Law [29] estimated the overall energy performance corresponding to five orientations of a STPV system installed in Hong Kong by integrating the simulation results of thermal, power and visual behaviours. The main finding of the work was that the system would lead to an annual electrical benefit of about $1300 \mathrm{kWh}$ in the best case orientation (south-east).

While recent years have seen an increasing number of building energy codes and standards focused to improve the energy efficiency of the construction sector [30-32], at present a specific standard that considers PV elements as constructive components does not yet exist or it is just starting to emerge [33]. In the specific case of glazing products, useful tools that enable designers to adopt energy effective project solutions, i.e. the integration of simulation software with reliable and detailed optical data like the IGDB (international glazing database) [34] or the newer CGDB (complex glazing database) [35] are being improved constantly, but STPV elements are still not properly considered.

Consequently, it is worth considering the performance of innovative STPV solutions in comparison with well-established constructive elements. Furthermore, a lack of research exists on the performance of multifunctional STPV façade in the Mediterranean region, characterized by a high annual solar irradiation and a wide range of ambient temperatures [16]. For these reasons, a performance comparison with conventional glazing in Mediterranean conditions is necessary in order to assess realistically the energy saving potential that STPV solutions might provide.

In this work the overall energy performance of five BIPV double glazing elements is evaluated in a specific location, Madrid (latitude $40.45^{\circ} \mathrm{N}$, longitude $3.71^{\circ} \mathrm{W}$, altitude $664 \mathrm{~m}$ ) whose main climatic characteristics are typical of the Mediterranean Basin ("dry-summer subtropical" climate classified as Csa according to Köppen climate classification) [36]. Each element corresponds to a specific degree of transparency moving from 0 (opaque element) to 40 (highest degree, visible transmittance value of approximately 0.4 ) to cover a transparency range representative of the market [3,37]. Prior to performing the comparative analysis, the elements have been experimentally characterized in order to obtain the spectral data necessary to execute a reliable simulation, based on the most advanced window modelling method that uses fully characterized spectral properties [38].

Due to the multifunctional role that STPV elements play in the building envelope, which affects heating, cooling and lighting loads, visual comfort as well as power generation, a set of specific simulation tools has been used to correctly characterize the behaviour of each element. To simplify the understanding of the study, the simulations have been applied to a typical office space.

To assess the energy saving potential of STPV solutions, their performances have been compared, over different WWRs (window-to-wall ratios), with a solar control double glass compliant with the Spanish Technical Building Code [30] in terms of $U$ and $g$ values, so supposedly the most diffused solution in the real world. In addition, in order to establish the importance of the transparency degree on the building energy balance, all STPV elements have been compared with each other.

The article content is as follows. Section 2 describes the experimental equipment used to perform the optical characterization of the STPV elements and the spectral data obtained. Section 3 presents the simulation methodology, the reference office model used to carry out the energy performance analysis and the metrics used to evaluate the performance the glazing elements. In Section 4 the results are discussed. Finally, in Section 5, the main findings are summarized and conclusions are drawn.

\section{Optical characterization}

The basic optical properties required to evaluate the thermal and daylighting performance of STPV multifunctional elements are their spectral reflectance and transmittance, according to EN410:2011 and EN673:2011 standards on glass in building [39,40]. It is worth mentioning that detailed spectral data are not normally available in the technical specifications of glazing systems, where only global characteristics as $U$-value, $g$-value as well as visible transmittance are specified by the manufacturers. In this sense, the IGDB [34] is a valuable source of information to perform accurate energy performance calculations of conventional glazing solutions but unfortunately PV industry products designed for building applications such as STPV elements are not yet included in the database. Consequently, in order to perform accurate energy 
Table 1

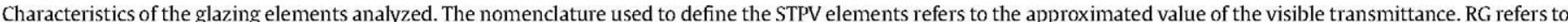
Reference Glass.

\begin{tabular}{|c|c|c|c|c|c|c|c|c|c|c|c|c|}
\hline $\begin{array}{l}\text { Glazing } \\
\text { element }\end{array}$ & Tvis & $\begin{array}{l}\text { Rvis } \\
\text { front }\end{array}$ & $\begin{array}{l}\text { Rvis } \\
\text { back }\end{array}$ & Tsol & $\begin{array}{l}\text { Rsol } \\
\text { front }\end{array}$ & $\begin{array}{l}\text { Rsol } \\
\text { back }\end{array}$ & $g$-value & $\begin{array}{l}U \text {-value } \\
{\left[\mathrm{W} / \mathrm{m}^{2} \mathrm{~K}\right]}\end{array}$ & $\begin{array}{l}\text { STC power } \\
\text { density }\left[\mathrm{W} / \mathrm{m}^{2}\right]\end{array}$ & $\begin{array}{l}\text { PV } \\
\text { technology }\end{array}$ & $\begin{array}{l}\text { Thickness } \\
{[\mathrm{mm}]}\end{array}$ & $\begin{array}{l}\text { Density } \\
{\left[\mathrm{kg} / \mathrm{m}^{2}\right]}\end{array}$ \\
\hline 0 & 0.003 & 0.077 & 0.582 & 0.002 & 0.168 & 0.464 & 0.145 & 2.783 & 61.95 & $\mathrm{a}-\mathrm{Si}$ & 21 & 25.4 \\
\hline 10 & 0.101 & 0.081 & 0.513 & 0.077 & 0.148 & 0.410 & 0.216 & 2.783 & 44.25 & $\mathrm{a}-\mathrm{Si}$ & 21 & 25.4 \\
\hline 20 & 0.158 & 0.085 & 0.469 & 0.120 & 0.157 & 0.373 & 0.253 & 2.783 & 37.93 & $\mathrm{a}-\mathrm{Si}$ & 21 & 25.4 \\
\hline 30 & 0.249 & 0.090 & 0.386 & 0.186 & 0.144 & 0.313 & 0.316 & 2.783 & 31.60 & $\mathrm{a}-\mathrm{Si}$ & 21 & 25.4 \\
\hline 40 & 0.324 & 0.100 & 0.337 & 0.242 & 0.141 & 0.273 & 0.367 & 2.783 & 25.28 & $a-S i$ & 21 & 25.4 \\
\hline RG & 0.461 & 0.189 & 0.229 & 0.382 & 0.189 & 0.170 & 0.473 & 2.783 & - & - & 20 & 25.0 \\
\hline
\end{tabular}

performance assessments it has been considered necessary to determine experimentally the optical characteristics of the STPV elements considered in this study. In this section the optical characterization process of the STPV elements, which are named 0,10 , $20,30,40$ corresponding to the visible transmittance approximated value (Table 1 ) is described.

\subsection{Experimental setup}

In order to perform the optical characterization of the different elements considered an UV/Vis/NIR spectrophotometer equipped with an integrating sphere has been used. It is a PerkinElmer ${ }^{\circledR}$ Lambda 900 spectrophotometer fitted with a Labsphere ${ }^{(8)}$ Inc. $150 \mathrm{~mm}$ integrating sphere (Fig. 1). This integrating sphere houses two detectors, a PbS detector for the UV/Vis region and an InGaAs detector for the NIR range. The advantage of using an integrating sphere with large enough entrance ports is the capacity to capture not only the primary reflected or transmitted beam but also enough secondary beams due to back reflectance and multiple reflections inside the complex samples with different layers, i.e. these ports are converted in the effective sense area of the detector.

\subsection{Experimental results}

Measurements were performed in the wavelength range $0.3-2.5 \mu \mathrm{m}$ to completely cover the solar energy range. Total hemispherical spectral transmittances on the front side and reflectances on the front and back sides were measured at normal incidence for all STPV elements. In Figs. 2-4, in which the samples are named in accordance with Table 1, the results are shown. In the case of the RG (reference glass), the spectral data define in the IGDB [34] were used.

Fig. 2 shows the measured total hemispherical transmittance spectra for the six glazing samples. The curves show an increase of
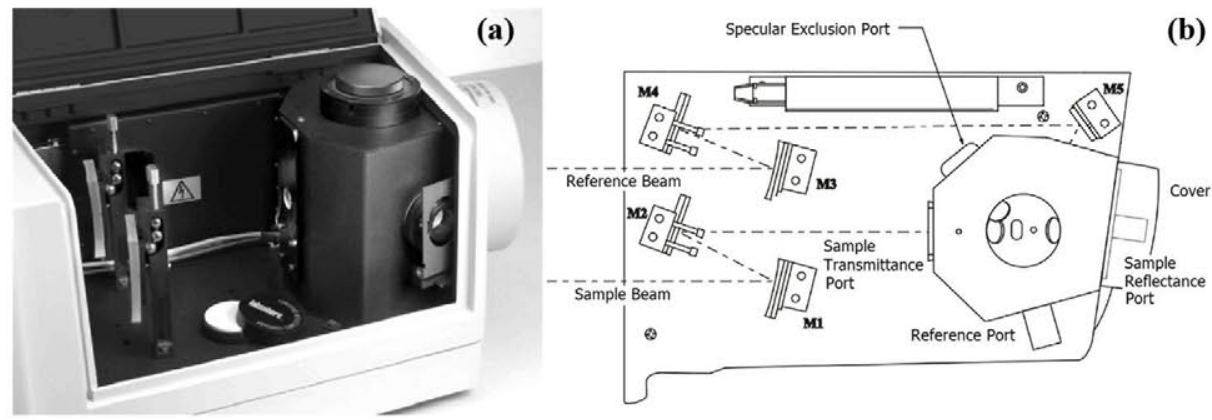

(b)

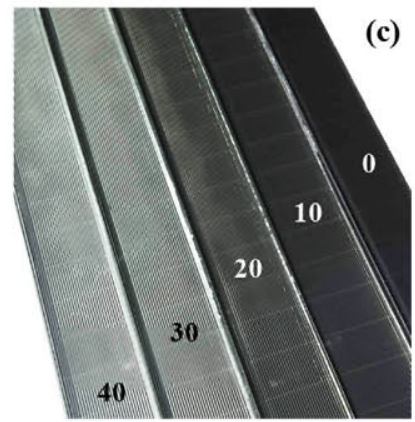

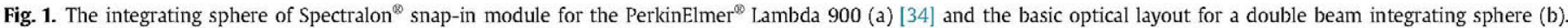
Figure (c) shows the samples of the modules used in the optical characterization.

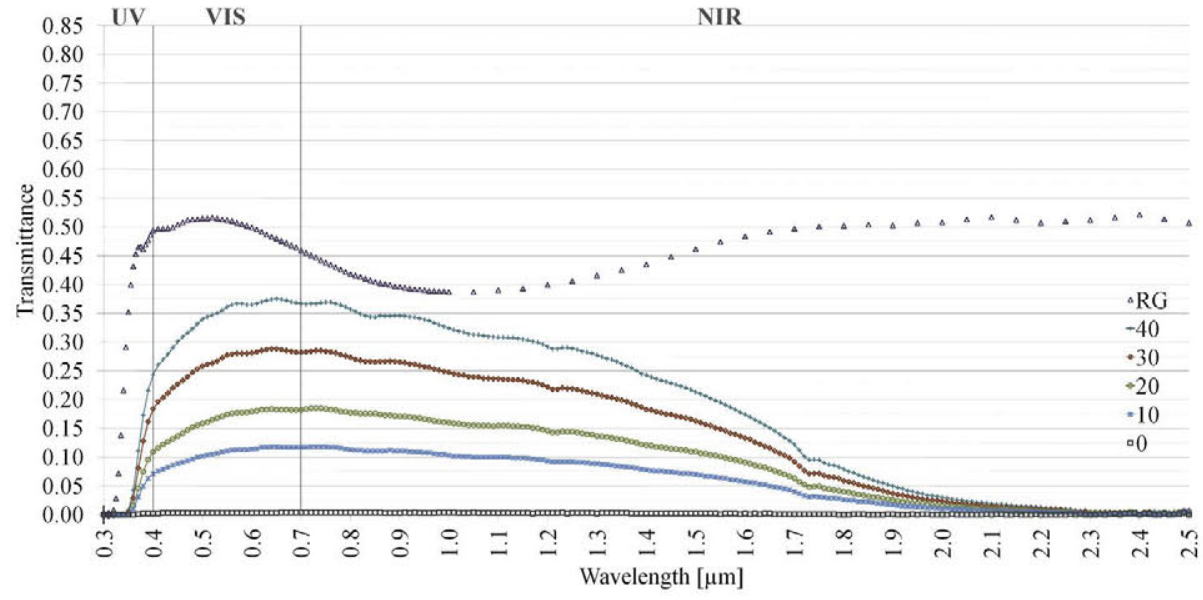

Fig. 2. Total hemispherical spectral transmittance of the glazing elements analyzed. 


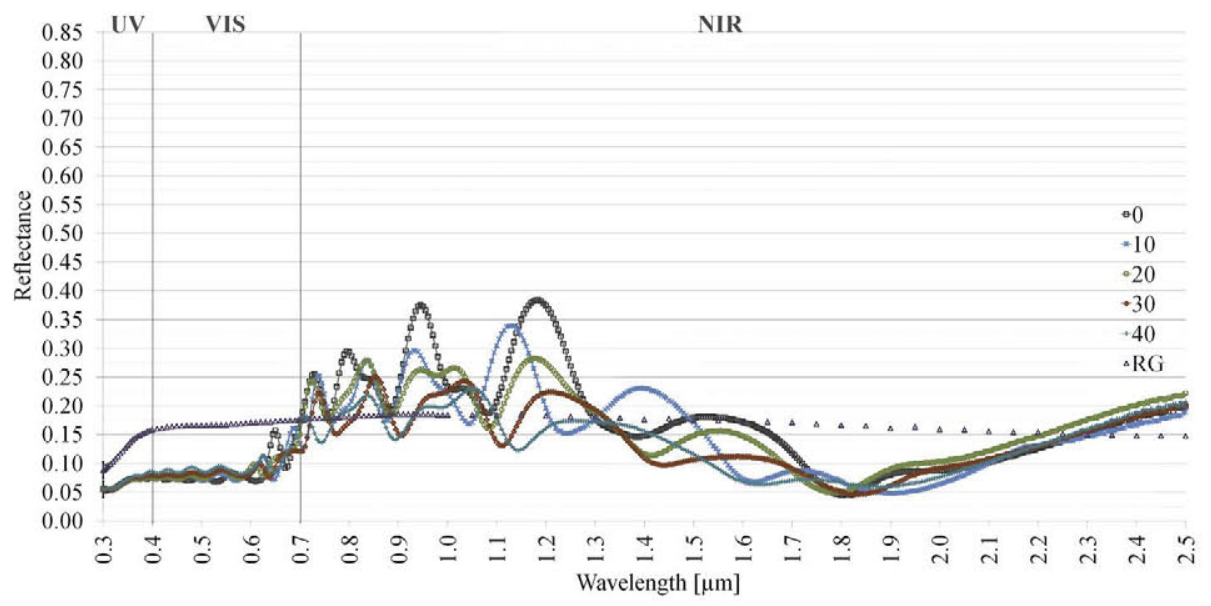

Fig. 3. Total hemispherical front side spectral reflectance of the glazing elements analyzed.

the spectral transmittance with the transparency degree of the samples, being the transmittance in the opaque sample practically negligible in all the spectral range. Besides, the spectral dependence of the rest of STPV glazings has a similar shape, which is different from that of the RG. In the UV and visible ranges the active material of the STPV elements absorbs part of the received radiation. As a result, the visible transmittance is modified in reference to a conventional glass, and it is shifted towards the red colour. In the NIR region, the STPV samples have a low transmittance compared to the RG and reduce the incoming near infrared radiation into the building.

The measured total hemispherical reflectance spectra of the front surface for the six glazing samples are represented in Fig. 3. In order to minimize the reflection losses, the frontal reflectance of the STPV elements shows a flat behaviour with a low value (around $7.5 \%$ in all the samples), for almost all the wavelengths in the a-Si spectral response range. Furthermore, the front reflectance in the NIR region exhibits an oscillating shape, different to the one of the $\mathrm{RG}$, but in the same order of values. Besides, in the neighbourhood of intermediate IR reflectance grows monotonically.

In Fig. 4, the measured total hemispherical back side reflectance spectra for the six glazing samples are represented. The obtained curves show a gradual decrease in reflectance with the transparency degree increase. The spectral dependence of the STPV glazings has a similar shape, which is different from the RG.
High reflectance of the rear glass and the metallic back contact of the PV cells in the visible and NIR regions provide high total reflectance to the STPV elements. In this regard it is striking that the back side design of PV elements, traditionally deemed to be of secondary importance by PV manufacturers in conventional applications focused on maximizing electricity output, should play a key role in improving both the energy performance and the aesthetics quality of STPV solutions where the PV elements replace traditional construction components in the building envelope.

Finally, as an example, Fig. 5 shows the entirely set of spectral measurements results for element 20 . In this case, the spectral transmittance and reflectance of both sides are drawn together to facilitate the comparison.

In summary, it must therefore be concluded that the PV layer of the STPV elements, including the active material and the back contact, define the transmittance and the back reflectance, whereas the front glass anti-reflection treatment has a big influence on the frontal reflectance.

\section{Overall performance simulation methodology}

Due to the multifunctional role that STPV plays in the building envelope, which affects the heating, cooling and lighting loads, the visual comfort as well as the power generation, a set of simulation

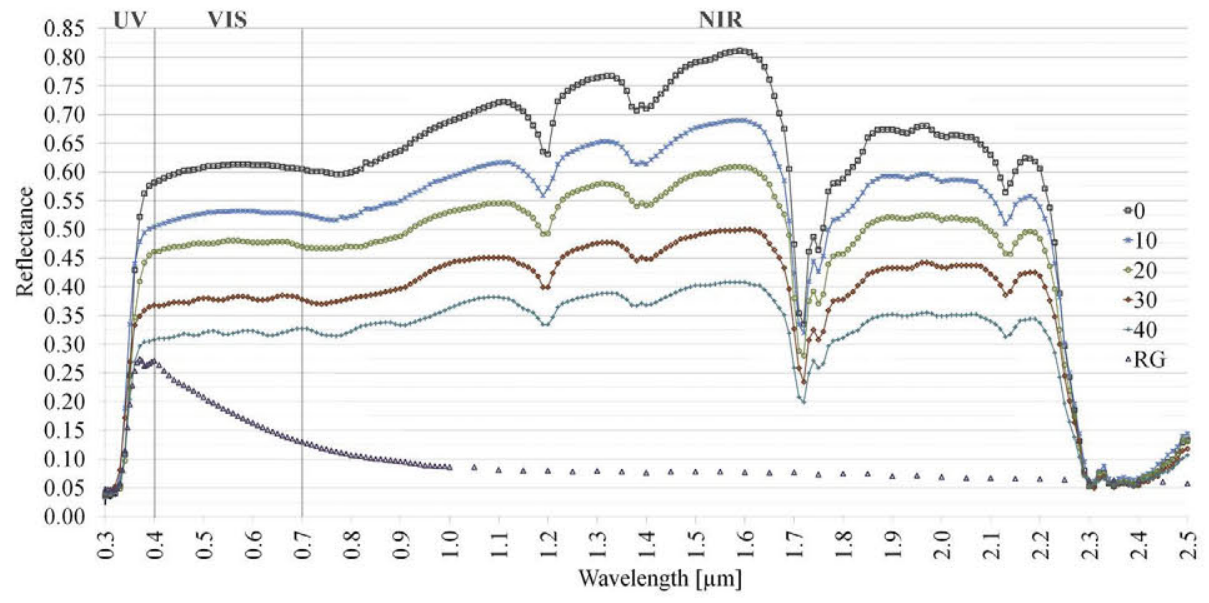

Fig. 4. Total hemispherical back side spectral reflectance of the glazing elements analyzed. 


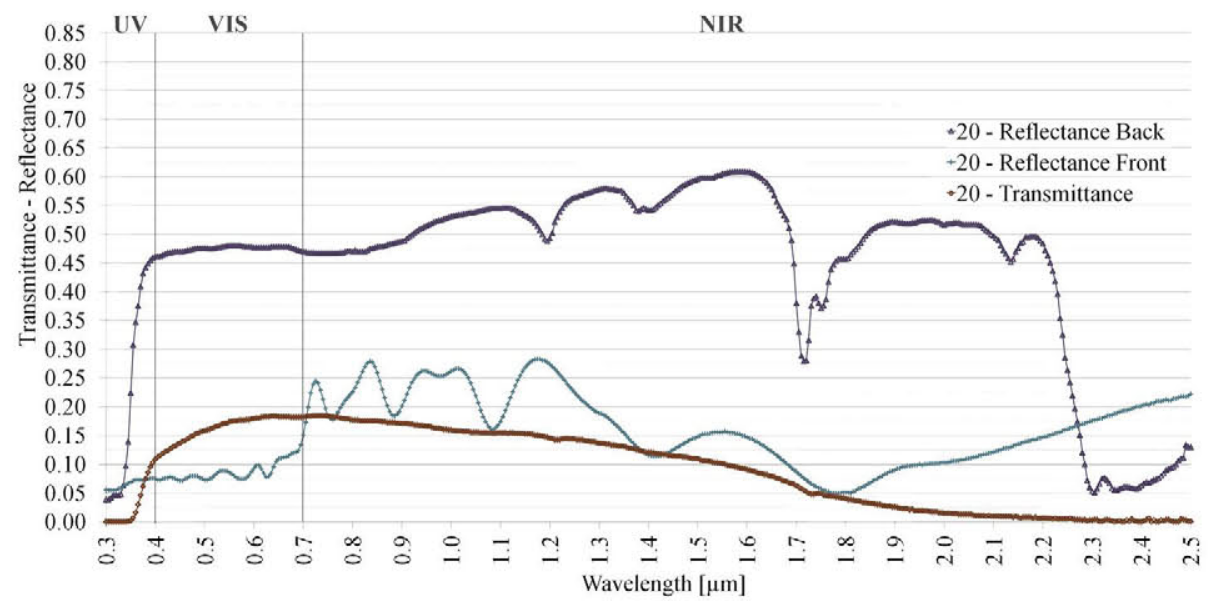

Fig. 5. Total hemispherical spectral transmittance and reflectance (front and back side) of the glazing element 20 , having a visible transmittance of $16 \%$.

tools has been used to correctly characterize the behaviour of each element. This is due primarily to the fact that none of the existing simulation tools, if used in a stand-alone manner, is capable of property taking into account all the effects of STPV integration on the building energy balance [41]. This approach allows combining the results of state-of-the-art tools in their respective fields, such as EnergyPlus in thermal calculations, PVSyst in PV generation estimation and Radiance-based software in visual comfort assessment. Furthermore, to properly carry out the analysis based on this method is necessary to verify that the physical phenomena related to two or more simulations are property modelled in each tool and no interaction amongst the programs can occur. For instance, the effect of the temperature on the PV system performance is an important issue that has to be considered. Accordingly, it has been verified that it is properly modelled in PVSyst, even if the behaviour of the façade in terms of thermal loads is evaluated using EnergyPlus. To perform the simulation a model of a reference office space was considered because the façade integration of STPV elements is particularly interesting in commercial buildings, having greater energy saving potential than residential premises [11,42]. In fact office buildings are normally occupied during daytime, are characterized by considerable lighting and internal loads that daylight utilization may contribute to reduce and present high vertical surfaces.

\subsection{Reference building}

The reference building, originally defined in the European Commission Joule projects REVIS and SWIFT [43] and further refined in the IEA Solar Heating and Cooling programme Tasks 25, 27 and 31 [44], is in a middle-size office building with office modules aligned on two façades, separated by a central corridor. Fig. 6 shows the whole building and the dimensions of the south oriented office module used in simulations.

The building is supposed to be located in Madrid, and has an unshaded, south-facing façade with a WWR of $44 \%$. To properly assess the daylighting potential of the glazing materials, the space was simulated assuming the most sophisticated lighting control model: a continuous lighting control dims continuously the artificial light output as the daylight illuminance fluctuates and switch off completely when the minimum dimming point (the target work plane illuminance of $5001 \mathrm{x}$ ) is reached. In such way the daylighting energy saving potential is taken into account as a reduction of the artificial lighting load. The lighting power density in the office is $8 \mathrm{~W} / \mathrm{m}^{2}$ and the space is occupied on weekdays from 8 AM to 7 PM. Fig. 7 summarizes the overall simulation approach.

\subsection{Thermal simulation}

All thermal simulations were carried out using the EnergyPlusbased DesignBuilder software [45]. For the simulation, it was assumed that the space is bordered on five sides by similar spaces, therefore interior walls, floors and ceilings were modelled adiabatically. The exterior wall has a U-value of $0.66 \mathrm{~W} / \mathrm{m}^{2} \mathrm{~K}$, according to the limit established in the Spanish Technical Building Code for the corresponding climatic zone [30]. The space is conditioned by means of a fan-coil unit coupled to a reversible heat pump system. To convert the thermal loads to electricity consumptions, the

(a)

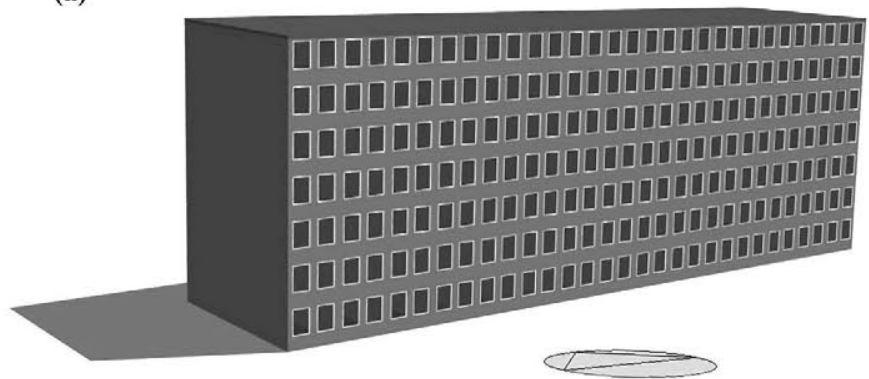

(b)

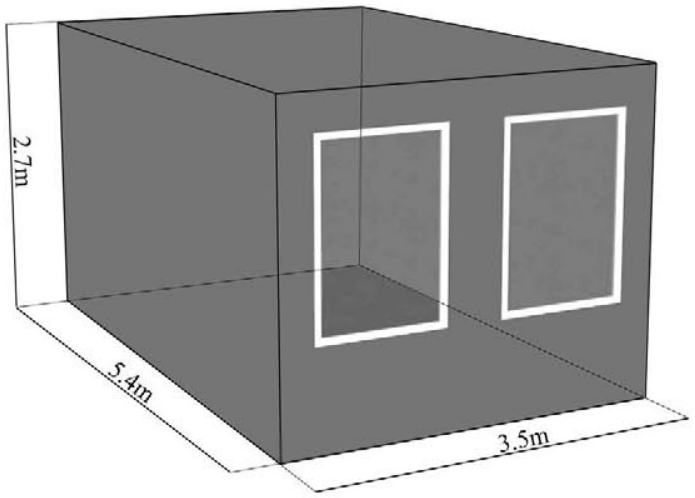

Fig. 6. Reference building (a) and dimensions of the office module used in simulations (b). 


\begin{tabular}{|c|c|c|c|}
\hline Glazing elements spectral characterization & Climate EPW data & Reference building & INPUT \\
\hline DesignBuilder EnergyPlus & PVsyst & Optics Window COMFEN & SIMULATION \\
\hline$\checkmark$ & OUTPUT & \\
\hline Cooling-Heating-Lighting loads + PV generation & DGI Illuminance maps & RESULTS \\
\hline
\end{tabular}

Fig. 7. Overall energy simulation approach.

simulation program default data of the coefficient of performance (1.67 both in heating and cooling mode) are used [45,46]. To justify such low default value, it is worth mentioning that in the simulation model used the COP value does not define the reversible heat pump peak efficiency, but represents the total seasonal efficiency of the whole HVAC system, including the distribution losses (fan and pump energy consumption) and the inefficiency of the control equipment. Heating and cooling setpoint and setback temperatures are $20^{\circ} \mathrm{C} / 12{ }^{\circ} \mathrm{C}$ and $26{ }^{\circ} \mathrm{C} / 28^{\circ} \mathrm{C}$ respectively being typical values normally used in HVAC applications. The experimentally measured spectral properties of the elements presented in Section 2 were included in the model to assess the expected performance of the façade-integrated systems. Climate EnergyPlus weather data for Madrid were used to perform the simulation.

\subsection{Daylighting simulation}

The visual comfort analyses were carried out using the LBNL (Lawrence Berkeley National Laboratory) daylighting software package consisting of Optics, Window and COMFEN tools [47-49]: Optics was used to import the experimental spectral data of the glazing materials; next, in order to perform the Radiance-based simulation the glazing systems were defined in Window and related data were finally exported to COMFEN. To evaluate the visual comfort both glare (based on the Daylighting Glare Index) and illuminance analysis (based on illuminance 3D contours maps and render visualizations), were carried out. Firstly the reference model was analyzed (WWR $=44 \%$ ), than the study was extended ranging the WWR from $11 \%$ to $88 \%$.

\subsection{Electrical simulation}

To estimate the photovoltaic electricity generation, PVSyst software was used [50]. This tool was selected because treats in detail several loss factors, such as optical, irradiance, mismatch and thermal losses, just to cite some examples. The operating temperature of the array (and the corresponding thermal loss) for instance is computed at each simulation step by solving the energy balance between the thermal power absorbed by the module and the thermal power exchanged between the module and the ambient. To execute the simulation, a base-case grid-connected photovoltaic system was defined, consisting of 5 modules $\left(4 \mathrm{~m}^{2}\right.$ available area, corresponding to a WWR $=44 \%$ ) and an appropriate commercial inverter. The electrical characteristics of the STPV elements and inverter were imported from the Photon International database [51,52] and five systems were simulated. Then, in order to estimate the electricity output corresponding to different WWRs, the base case output corresponding to the five different transparency degrees considered (see Table 2) was adjusted by means of linear interpolation based on the available area in each case.

\subsection{Integrated energy balance}

To assess the overall energy performance of the glazing elements analyzed (Table 1), the heating, cooling, lighting loads as well as the photovoltaic generation were calculated on an annual basis using hourly time step simulation. The parameter proposed to evaluate the annual energy performance of the glazing elements, named $E B I$ (energy balance index), represents the building energy balance in terms of electricity and is calculated as shown in Equation (1):

$\mathrm{EBI}=\mathrm{CED}+\mathrm{HED}+\mathrm{LED}+\mathrm{PEG} \quad\left[\mathrm{kWh} / \mathrm{m}^{2}\right]$

where CED is the annual cooling energy demand, HED is the annual heating energy demand, LED is the annual lighting energy demand and PEG is the annual photovoltaic energy generation. Notice that the values corresponding to energy demand, i.e. CED, HED, and LED are positive whereas the energy generation value PEG is negative. The choice of the signs is necessary to ensure the consistency of the equation, since the energy flows (energy demand vs energy generation) are characterized by opposed directions. All the values are expressed in $\mathrm{kWh}$ and normalized to the net space floor area. To determinate the energy demand and generation values used to calculate the $E B I$, all the boundary conditions regarding the model characteristics (envelope properties, HVAC systems, internal gains, occupation schedules, etc.) are kept constant (assuming the values described in Sections 3.1-3.4) and only the WWR and the STPV elements are modified, precisely to highlight the effect of these parameters over the space energy balance. Thus the EBI, which is an indicator of the building energy performance, is used here as an indicator of the different façade STPV systems global performance, since the remaining building characteristics are invariant throughout the research. According to Equation (1), the lower the value of the EBI, the more effective the glazing element is in an annual energy performance basis. In this sense, the EBI complements other parameters used to assess the building energy performance, such as the Energy Performance Index, mainly used in Europe, or the Energy Use Intensity principally used in America [53], which are defined as the site energy consumption per unit of net

Table 2

Electrical characteristics of the PV glazing elements analyzed. Parameters $\alpha, \beta$ and $\gamma$ refer to $I_{\mathrm{SC}}, V_{\mathrm{OC}}$ and $P_{\mathrm{M}}$ temperature coefficients respectively.

\begin{tabular}{llllllllll}
\hline $\begin{array}{l}\text { Glazing } \\
\text { element }\end{array}$ & PV-tech & $\begin{array}{l}I_{\mathrm{SC}} \\
{[\mathrm{A}]}\end{array}$ & $\begin{array}{l}V_{\mathrm{OC}} \\
{[\mathrm{V}]}\end{array}$ & $\begin{array}{l}I_{\mathrm{MP}} \\
{[\mathrm{A}]}\end{array}$ & $\begin{array}{l}V_{\mathrm{MP}} \\
{[\mathrm{V}]}\end{array}$ & $\begin{array}{l}P_{\mathrm{M}} \\
{[\mathrm{W}]}\end{array}$ & $\begin{array}{l}\alpha \\
{\left[\% /{ }^{\circ} \mathrm{C}\right]}\end{array}$ & $\begin{array}{l}\beta \\
{\left[\% /{ }^{\circ} \mathrm{C}\right]}\end{array}$ & $\begin{array}{l}\gamma \\
{\left[\% /{ }^{\circ} \mathrm{C}\right]}\end{array}$ \\
\hline 0 & $\mathrm{a}-\mathrm{Si}$ & 1.05 & 64.5 & 0.95 & 51.7 & 48.9 & +0.09 & -0.28 & -0.19 \\
10 & $\mathrm{a}-\mathrm{Si}$ & 0.89 & 59.5 & 0.77 & 45.4 & 34.9 & +0.09 & -0.28 & -0.19 \\
20 & $\mathrm{a}-\mathrm{Si}$ & 0.79 & 59.5 & 0.68 & 44.1 & 30.0 & +0.09 & -0.28 & -0.19 \\
30 & $\mathrm{a}-\mathrm{Si}$ & 0.64 & 59.5 & 0.56 & 44.6 & 25.0 & +0.09 & -0.28 & -0.19 \\
40 & $\mathrm{a}-\mathrm{Si}$ & 0.52 & 59.5 & 0.44 & 45.2 & 19.9 & +0.09 & -0.28 & -0.19 \\
\hline
\end{tabular}



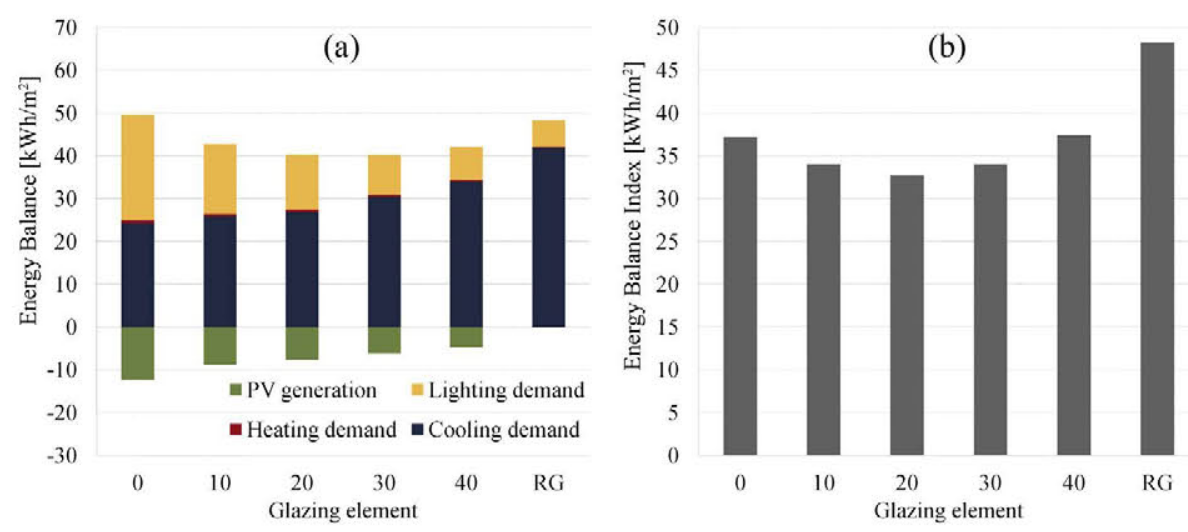

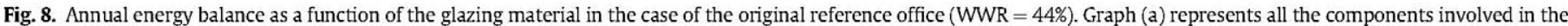
balance, reporting as positive the energy consumption and as negative the energy generation. Graph (b) reports the net energy balance index (EBI) values.

floor area. The new balance index aims to reflect the increasingly electricity generation role required to the buildings in order to minimize the residual demand of grid electricity. In this regard, the parameter, which includes both building electricity consumption and generation, is useful to compare the performance of alternative multifunctional solutions that integrate strategies focused to reduce the energy demand and increase the on-site generation, such as the STPV systems. Furthermore, the parameter allows estimating how close is the building performance to the net zero energy balance. For these reasons in the EBI calculation not only the site energy consumption per unit of net floor area is taken into account, but also the local PV generation.

\section{Results and discussion}

To evaluate the glazing material performance the annual $E B I$ has been calculated for the six glazing elements. As an example in Fig. 8 the results corresponding to the base case with a WWR $=44 \%$ are shown. Graphs (a) and (b) show the annual $E B I$ as a function of glazing material, with the difference that in (a) all the components of the energy balance are reported, while (b) represents only the annual net $E B I$ values. By looking at the (a) graph it can be noted that increasing the transparency degree of the glazing material: i) the cooling demand increases (higher solar gains), ii) the lighting demand decreases (more daylighting) and iii) the PV generation decreases (because the conversion efficiency of STPV elements is inversely proportional to the transparency degree, as can be seen looking at Table 1). Concerning the heating demand it can be noted that the values calculated, in the specific case analyzed (building located in Madrid, south-oriented and with the entire envelope modelled as adiabatic with the exception of the façade) are barely visible so in this case the heating demand can be considered negligible. By looking at graph (b), it may be observed that the element 20 outperforms the other solutions (lower EBI value) because it combines good annual values in daylighting supply, solar shading and electricity generation. Nevertheless it can be noted that for elements 10,20 and 30 (visible transmittance ranging between $10 \%$ and $25 \%$ ) the energy balance components vary appreciably (Fig. 8 (a)) but the overall energy performance is almost constant (Fig. 8 (b)). However, it is important to emphasize that all the STPV elements improve the building energy efficiency compared to the RG solution, providing a $E B I$ reduction ranging between $22 \%$ (element 40 ) and $32 \%$ (element 20 ).

To evaluate not only the glazing material performance but also the effect of the façade openings dimensions, the $E B I$ has been calculated for a wide WWR range, moving from $11 \%$ to $88 \%$. As an example in Fig. 9 the annual results corresponding to glazing element 20 are shown. By looking at graph (a) it can be noted that increasing the WWR: i) the cooling demand increases (higher solar gains), ii) the lighting demand decreases (more daylighting) and iii) the PV generation increases (bigger STPV active surface). Also in this case the heating demand, which increases with WWR, is considerably less significant than the other variables, being appreciable for high WWR only. By looking at the graph (b), it should be concluded that using the glazing material 20, the WWR that minimizes the $E B I$, i.e. that optimizes the building energy
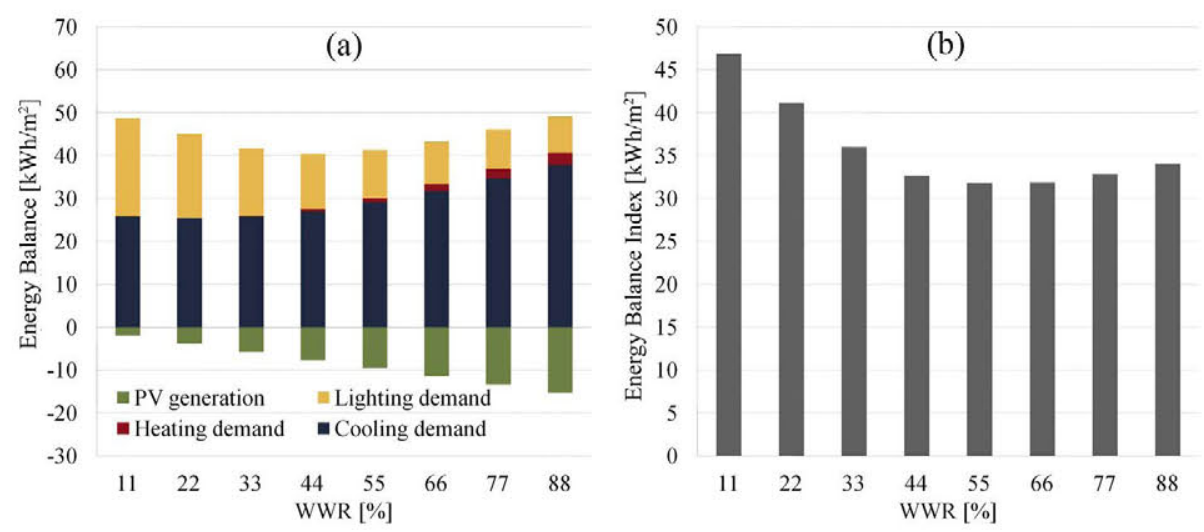

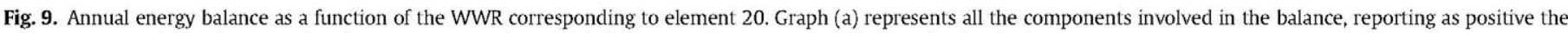
energy consumption and as negative the energy generation. Graph (b) reports the net energy balance index (EBI) values. 
performance, is represented by $55 \%$. It can be also noticed that the performances for WWR between $44 \%$ and $88 \%$ are very similar, with a relative variation between them below $7 \%$.

\subsection{Parametric analysis on glazing material and window-to-wall ratio}

Fig. 10 shows the annual Energy Balance Index as a function of the glazing material for the WWRs analyzed. The first result that stands out is that for reduced WWR the glazing material does not affect significantly the energy balance of the building zone whereas marked differences can be noticed for bigger façade openings. To highlight this behaviour the energy saving potential between the most efficient STPV solution and the RG is computed as $\nabla(E B I)$, reduction of Energy Balance Index. As shown, for WWR $\leq 22 \%$, the energy behaviour of all the elements is quite similar, being the saving potential provided by the best performing STPV solution compared to the RG lower than $6 \%$ (Fig. 10 (b)). For WWR $\geq 33 \%$, the energy saving potential starts to increase significantly and ranges between $18.2 \%(W W R=33 \%$, Fig. $10(\mathrm{c})$ ) and $59.1 \%(W W R=88 \%$, Fig. $10(h)$ ). Regarding the original reference office (WWR $=44 \%$ ), approximately one third of the energy demand could be saved using the glazing element 20 instead of the RG (Fig. 10 (d)). The impact of such demand reductions not only should be regarded in terms of economic savings, environmental aspects such as operational $\mathrm{CO}_{2}$ emissions reduction would provide a more exemplifying picture of renewable contribution to building sustainability [54].

Another point to consider when examining the glazing elements performance is to compare the STPV optimum solution not only with the RG, but also with the other STPV elements, in order to investigate the relevance of choosing an appropriate degree of transparency over the building energy balance. As can be seen in Fig. 10, for WWR up to $33 \%$ the energy behaviour of the five active elements is quite similar, with a maximum $E B I$ difference between the most efficient (element 30) and the least efficient (element 0 ) of about $10.5 \%$. For intermediate values of the WWR (44\%-55\%), element 20 outperforms other solutions and the STPV elements performance begins to differ significantly, being the maximum $E B I$ difference between the most and the least efficient element (element 40 ) of about $21.3 \%$. For WWR $\geq 66 \%$, element 10 seems to be the best solution, providing the lowest $E B I$ value. In this case, choosing a suitable degree of transparency is crucial, since the maximum energy balance difference between the best and worst solution (element 40 ) rises up to $40.5 \%$.

To summarize the previous results, the building space energy performance index EBI has been normalized to the best WWRglazing element combination (WWR $=77 \%$ combined with element 10) and results are shown in Table 3. As can be seen, the best solutions concentrate around the upper right-hand part of the diagonal, corresponding to elevate WWR values and low degree of transparency elements. It is worth noting that using the RG for WWR $>66 \%$, the building zone energy demand is at least twice the energy demands reached in the best case, i.e. using STPV 10. A colour range from green to red has been used to highlight the efficiency of the solutions.

\subsection{Daylighting analysis - visual comfort}

While the previous section presented a proposal to evaluate the overall energy performance of active photovoltaic glazing systems, the aim of this section is to estimate the visual comfort provided by the different solutions. To this end, DGI (daylighting glare index) and Illuminance Contour Maps are selected. Three typical days of the year were selected for DGI and Illuminance calculations: $21 \mathrm{Mar}$ (spring equinox), 21 June (summer solstice), and $21 \mathrm{Dec}$ (winter solstice). These days have been chosen to represent average
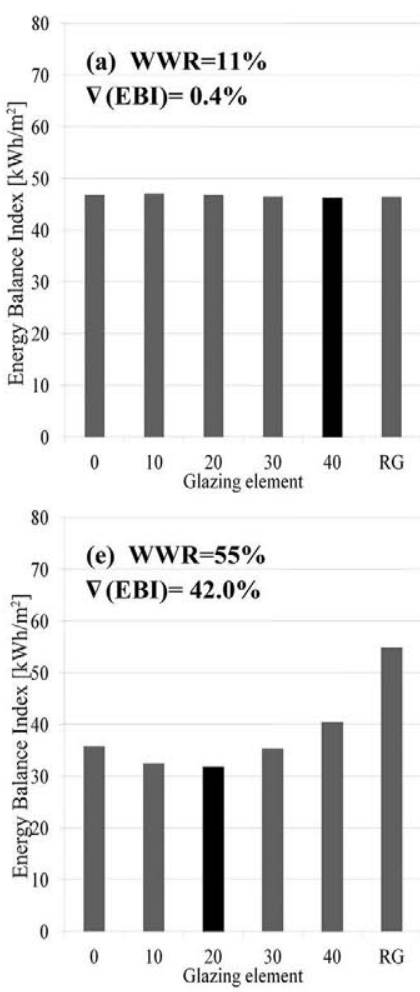
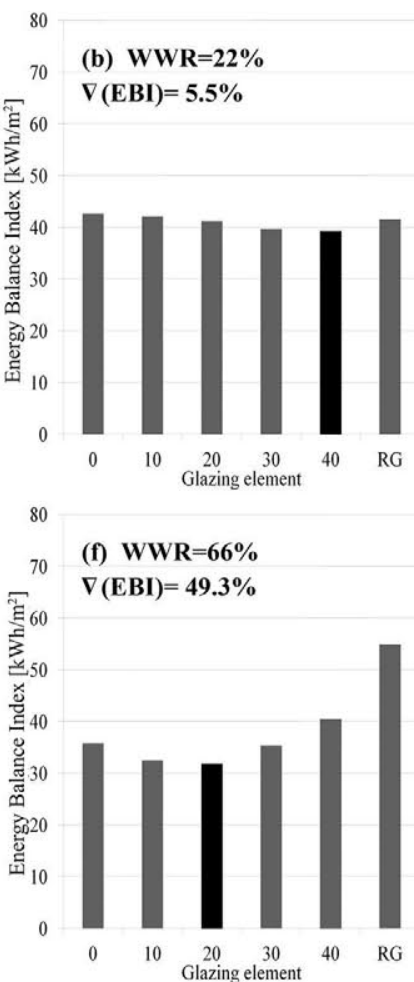
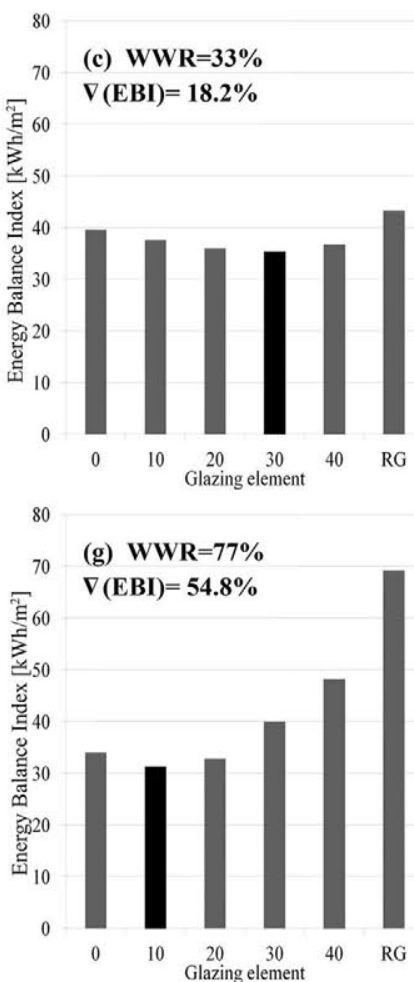
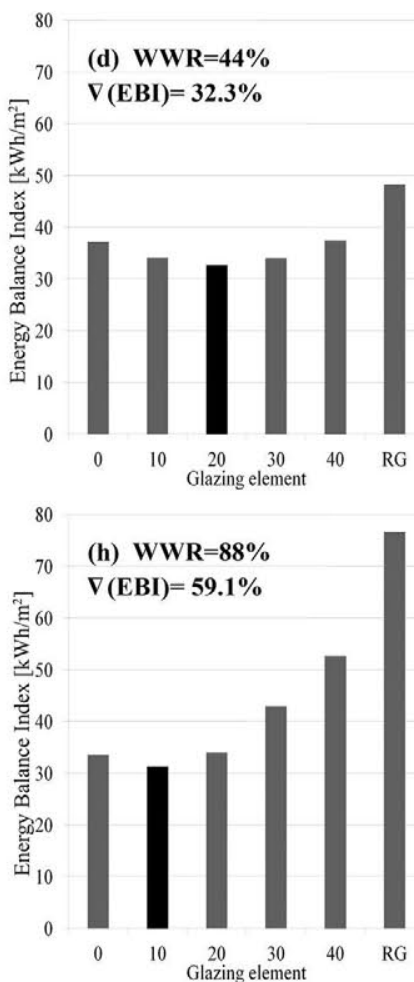

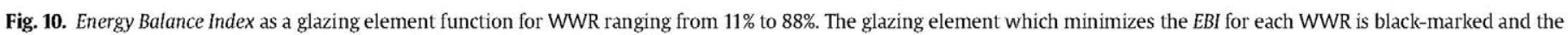
$E B I$ percentage difference between the best solution and the RG is included. 
Table 3

Normalized Energy Balance Index to the best performance WWR-glazing element combination, corresponding to glazing element 10 and WWR $=77 \%$.

\begin{tabular}{|c|c|c|c|c|c|c|c|c|c|}
\hline & & \multicolumn{8}{|c|}{ WWR } \\
\hline & & 11 & 22 & 33 & 44 & 55 & 66 & 77 & 88 \\
\hline \multirow{6}{*}{ 号至 } & 0 & 1.50 & 1.36 & 1.26 & 1.19 & 1.14 & 1.11 & 1.09 & 1.07 \\
\hline & 10 & 1.50 & 1.35 & 1.20 & 1.09 & 1.04 & 1.00 & 1.00 & 1.00 \\
\hline & 20 & 1.50 & 1.32 & 1.15 & 1.04 & 1.02 & 1.02 & 1.05 & 1.09 \\
\hline & 30 & 1.49 & 1.27 & 1.13 & 1.09 & 1.13 & 1.19 & 1.28 & 1.37 \\
\hline & 40 & 1.48 & 1.26 & 1.17 & 1.20 & 1.29 & 1.41 & 1.54 & 1.68 \\
\hline & RG & 1.49 & 1.33 & 1.38 & 1.54 & 1.76 & 1.98 & 2.21 & 2.45 \\
\hline
\end{tabular}

Table 4

Daylight Glare Index scale.[47].

\begin{tabular}{ll}
\hline DGl & Subjective glare assessment \\
\hline 16 & Just perceptible \\
20 & Just acceptable \\
22 & Borderline between comfort and discomfort \\
24 & Just uncomfortable \\
28 & Just intolerable \\
\hline
\end{tabular}

(equinox) and extreme (solstice) sky conditions and the nomenclature used refers to the northern hemisphere, being the reference building located in Madrid. Also, three time slots (9 AM, 12 PM, $3 \mathrm{PM}$ ) were selected to take into account different sun azimuth and elevation angles.

\subsection{1. $D G I$ (daylight glare index)}

DGI is a measure of glare based on the glare source luminance, glare source size, surround background luminance, and the location of the glare source relative to the occupant's field of view [55]. To carry out the DGI calculations, the Radiance utility tool included in COMFEN was used. The results under clear and overcast sky conditions are reported in Table 5 whereas the DGI values corresponding to a subjective user assessment of glare are displayed in Table 4. As shown, under clear sky conditions in the spring equinox and summer solstice comfort conditions are provided by all the glazing systems, being the DGI lower than 22 , even if a slight increase glare probability is noticed for high degree of transparency solutions $(30,40, \mathrm{RG})$. In the winter solstice, as expected, the highest DGI values are reached: in this case, uncomfortable conditions occur using all the glazing materials at midday. However, glazing element 10 provides much less discomfort than the other solutions, providing an effective sun-shading function as evidenced by the close to comfort zone DGI value (DGI $=22.1$ ). As an example of the glare control possibilities, Fig. 11 shows the rendered view for glazing elements 10 (a) and 30 (b) under clear sky condition at noon of winter solstice. The views are taken using a fisheye camera $\left(180^{\circ}\right.$ cone of vision) whose position is shown in Fig. 11 (c). As can be noted, although the DGI values of both glazing element are similar, element 10 seems to provide a considerably more comfortable daylighting because the light within the field of vision of an observer is not so bright than using element 30 . Under overcast sky conditions no glare problems have been observed, being 18.9 the maximum DGI value registered and corresponding to the RG, at $3 \mathrm{PM}$ in the summer solstice.

\subsubsection{Illuminance contour maps}

Fig. 12 and Fig. 13 represent illuminance contour maps for the camera position marked in Fig. 11 (c) at noon (12 PM) under clear and overcast skies respectively. Coloured lines define almost homogenous illuminance zones (illuminance variation less than $100 \mathrm{~lx}$ ), ranging from 50lx (violet (in web version)) to 950lx (yellow(in web version)). Thus this representation allows visualizing the daylighting pattern provided by the glazing elements and analyzing the degree of transparency effect. Fig. 12 shows that under clear skies the maximum illuminance values provided by the different glazing elements mostly differ in the spring equinox and winter solstice: in these days the maximum illuminance over the floor ranges between 150lx (element 10) and 950lx (RG) and between 50lx (element 10) and 850lx (RG) respectively. On the other hand, in the summer solstice, the solar elevation causes that illuminance variation using the same glazing elements is less marked, ranging the maximum illuminance between 50lx and 350lx. In any case, it is interesting to observe that in nearly all of the cases, the maximum illuminance value falls within the range $1001 \mathrm{x}-2000 \mathrm{~lx}$ considered as offering potentially useful illumination for the occupants of the space [56,57].

Regarding overcast sky conditions, the illuminance distribution can be assumed to be practically invariant to the glazing element used, as the Radiance visualizations in Fig. 13 suggest: in nearly all of the cases the maximum illuminance over the floor is lower than 50lx, thus the daylighting potential could be considered negligible.

\section{Conclusions}

In this study, an integral energy simulation methodology of STPV elements, covering thermal, daylighting and electrical performance has been proposed. To carry out the simulations, the glazing solutions have been previously experimentally characterized, using a spectrophotometer system coupled with an integrating sphere. The measures have allowed identifying the spectral transmittance (front) and reflectance (front and back) of the samples, necessary input data to perform detailed and reliable simulations. To complete the simulations, a reference office space has been considered and a package composed of a range of specific software tools has been used: DesignBuilder and EnergyPlus to carry out the thermal analysis, PVsyst to estimate the electricity generation and LNBL daylighting programs (Optics, Window and

Table 5

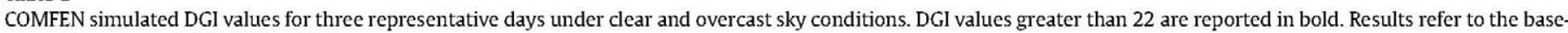
case reference model (WWR $=44 \%$ ).

\begin{tabular}{|c|c|c|c|c|c|c|c|c|c|c|c|c|c|c|c|}
\hline & \multicolumn{3}{|l|}{10} & \multicolumn{3}{|l|}{20} & \multicolumn{3}{|l|}{30} & \multicolumn{3}{|l|}{40} & \multicolumn{3}{|l|}{$\mathrm{RG}$} \\
\hline & $9 \mathrm{AM}$ & $12 \mathrm{PM}$ & $3 \mathrm{PM}$ & $9 \mathrm{AM}$ & $12 \mathrm{PM}$ & $3 \mathrm{PM}$ & $9 \mathrm{AM}$ & $12 \mathrm{PM}$ & $3 \mathrm{PM}$ & $9 \mathrm{AM}$ & $12 \mathrm{PM}$ & $3 \mathrm{PM}$ & $9 \mathrm{AM}$ & $12 \mathrm{PM}$ & $3 \mathrm{PM}$ \\
\hline \multicolumn{16}{|c|}{ Clear sky } \\
\hline $21-3$ & 6.6 & 4.1 & 0.0 & 12.7 & 9.7 & 0.0 & 14.3 & 10.4 & 0.0 & 16.4 & 12.0 & 0.0 & 17.7 & 13.0 & 0.0 \\
\hline $21-6$ & 8.6 & 3.3 & 0.0 & 15.9 & 17.2 & 15.4 & 17.6 & 18.2 & 16.0 & 19.3 & 19.9 & 17.7 & 17.0 & 20.7 & 18.4 \\
\hline $21-12$ & 0.0 & 22.1 & 13.5 & 5.6 & 24.1 & 16.9 & 9.7 & 24.9 & 18.1 & 11.6 & 26.2 & 19.6 & 13.4 & 26.8 & 20.2 \\
\hline \multicolumn{16}{|c|}{ Overcast sky } \\
\hline $21-3$ & 0.0 & 6.2 & 6.8 & 0.0 & 12.0 & 12.1 & 9.4 & 14.3 & 13.7 & 12.6 & 15.8 & 0.0 & 13.6 & 16.9 & 17.1 \\
\hline $21-6$ & 4.4 & 9.2 & 8.5 & 10.9 & 13.7 & 12.7 & 12.8 & 15.2 & 15.4 & 15.8 & 17.2 & 17.3 & 16.2 & 18.8 & 18.9 \\
\hline $21-12$ & 0.0 & 0.0 & 1.7 & 0.0 & 8.5 & 8.0 & 0.0 & 10.7 & 10.0 & 0.0 & 13.6 & 13.4 & 1.3 & 15.1 & 14.7 \\
\hline
\end{tabular}




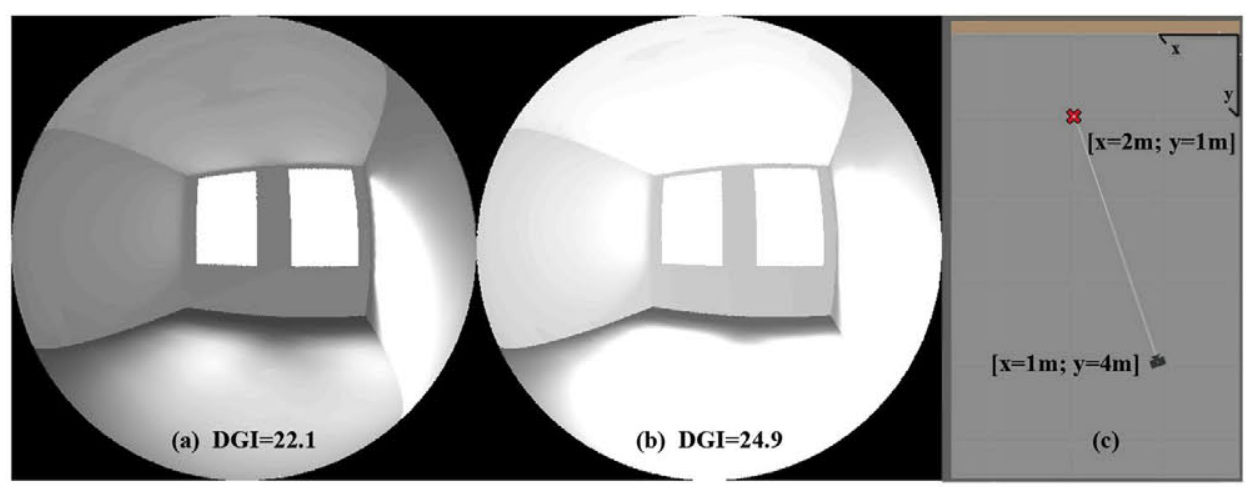

Fig. 11. Rendered views using glazing elements 10 (a) and 30 (b) under clear sky condition at noon in the winter solstice, (c) shows the camera position.

COMFEN) to evaluate the visual comfort. To assess the overall energy performance of the glazing elements, a parameter called $E B I$ (energy balance index) that takes into account annual heating, cooling and lighting loads, as well as the electricity generation has been defined. This parameter, which expresses the building net electricity balance per unit of net floor area, is a useful indicator of the overall building energy performance and allows assessing the energy performance of STPV façade systems. According to the comparative analysis performed, the remarkable findings of this work are listed below.

Five different commercial STPV elements representative of the current marker (visible transmittance between $0 \%$ and $32 \%$ ) have been analyzed together with a reference glass complying with the local building regulations from Spain (location Madrid). Comparing the performance of the STPV elements with the code-compliant reference glass, to fully exploit the energy saving potential of these glazing solutions it might be concluded that:

- For small façade openings (WWR $\leq 22 \%$ ) the energy saving potential provided by the best performing STPV solution compared to the RG is lower than $5.5 \%$, so probably in this case it would not be worth implementing the STPV solution;

- For intermediate and large façade openings (WWR $\geq 33 \%$ ), the STPV solutions provide a promising energy saving potential, ranging between $18 \%(W W R=33 \%)$ and $59 \%(W W R=88 \%)$ compared to the RG.

Comparing the performance of the STPV elements between them, to point out the degree of transparency effect and the importance of an adequate selection of this parameter, we can conclude that:

- For relative small façade openings (WWR $\leq 33 \%$ ) the energy performance of all STPV elements is reasonably similar, with a maximum EBI difference between elements of about $10 \%$;

- For intermediate façade openings $(33 \%<$ WWR $<66 \%)$ the second less transparent STPV element (visible transmittance of $16 \%$ ) outperforms the other solutions being about $25 \%$ more efficient than the least efficient STPV element (visible transmittance of $32 \%$;

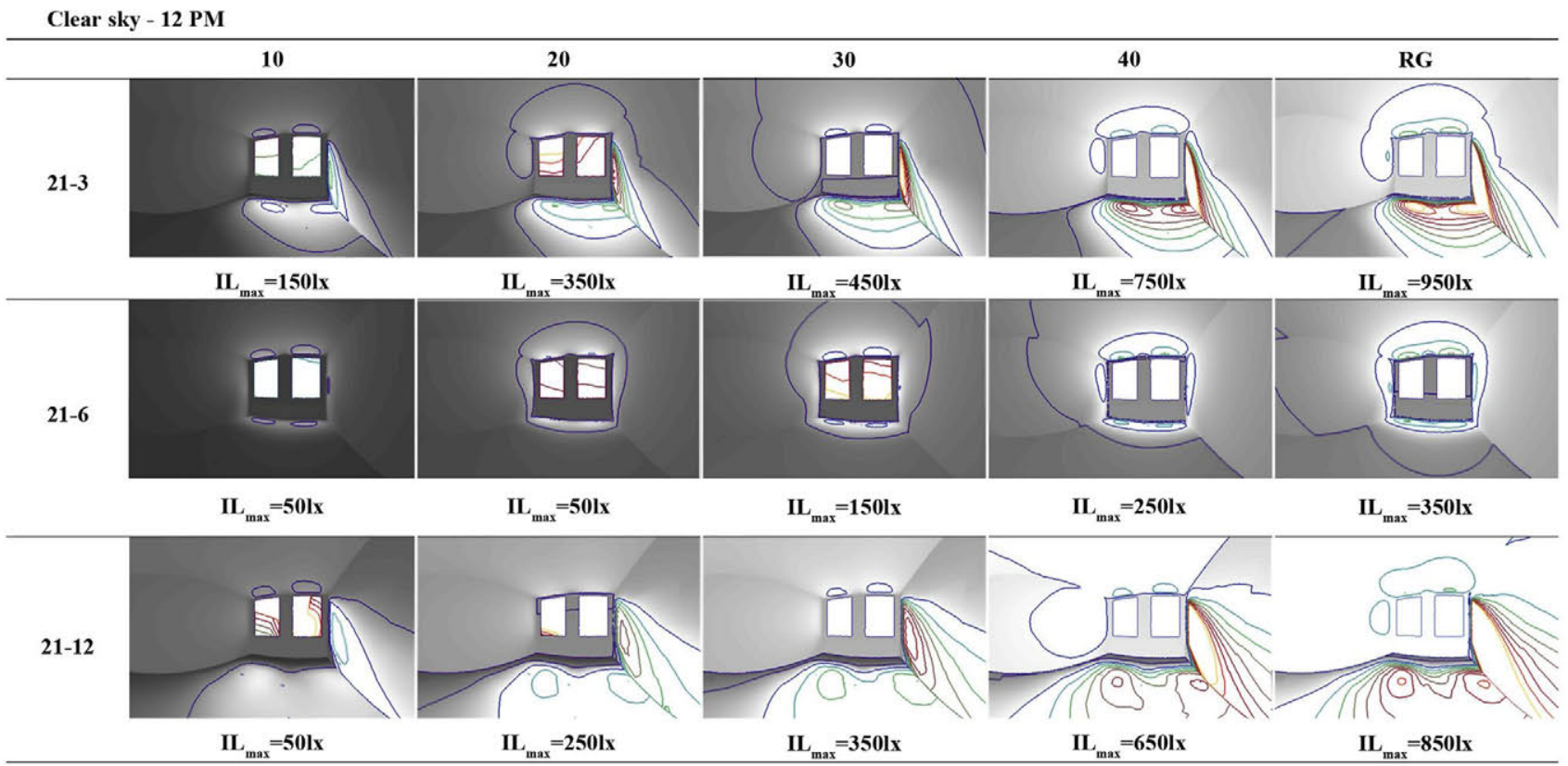

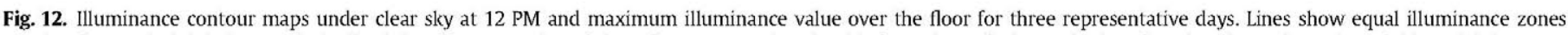
ranging from 50lx (violet) to 950lx (yellow). (For interpretation of the references to colour in this figure legend, the reader is referred to the web version of this article.) 


\begin{tabular}{|c|c|c|c|c|}
\hline 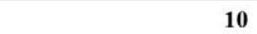 & 20 & 30 & 40 & RG \\
\hline $21-3$ & & & & \\
\hline
\end{tabular}
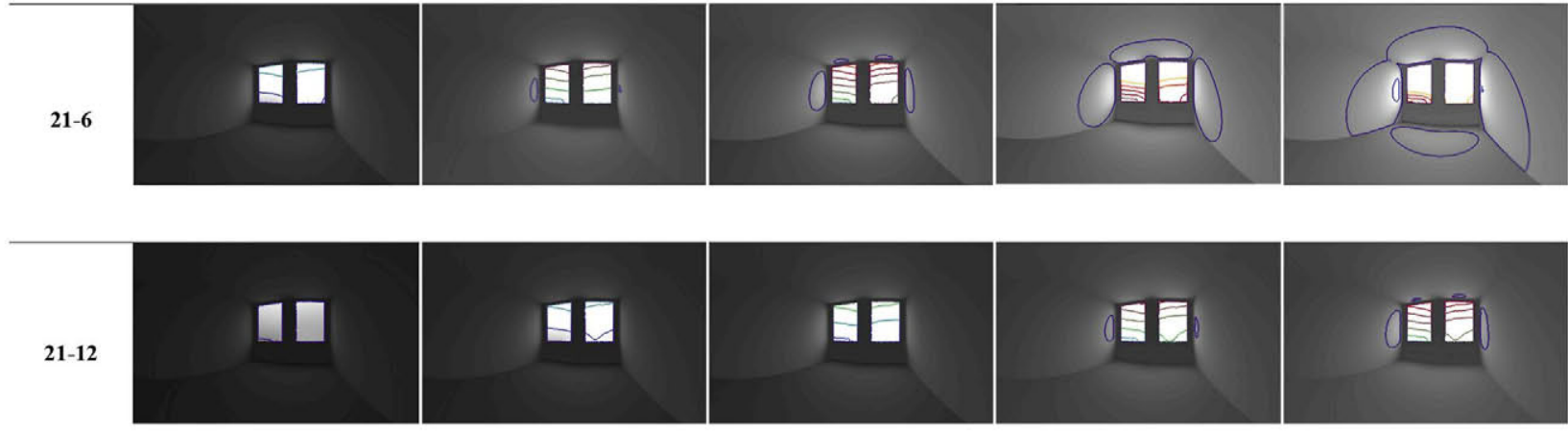

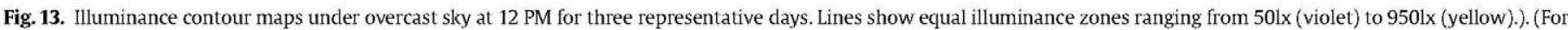
interpretation of the references to colour in this figure legend, the reader is referred to the web version of this article.)

- For large façade openings (WWR $\geq 66 \%$ ), the less transparent STPV element (visible transmittance of $10 \%$ ) provides the most efficient energy balance and in this case the performance of the different glazing material diverges drastically, rising up to $68 \%$ the difference between the best and the worst STPV solution (most transparent element, visible transmittance of $32 \%$ ).

Regarding the glare and daylighting analysis, the main findings are that:

- Under clear skies in the spring equinox and summer solstice no glare conditions occur at noon. In the winter solstice uncomfortable conditions occur using all the glazing materials, thought the least transparent STPV provides close to comfort conditions;

- Under clear skies, in nearly all of the cases the maximum illuminance value over the floor falls within the range $100 \mathrm{l}-2000 \mathrm{~lx}$ considered as offering potentially useful illumination for the space users;

- Under overcast sky conditions illuminance over the floor is lower than 50lx. Accordingly the daylighting potential in these conditions could be considered negligible.

In summary it has been shown that the use of active photovoltaic glazing systems can significantly contribute to reduce the building energy demand. Moreover, it has been shown that a rigorous analysis methodology based on the STPV optical characterization and on the utilization of complementary software tools:

- Is an adequate approach in order to properly and realistically quantify the STPV elements potentiality, as well as provide guidance on optimization possibilities of these elements;

- Is hardly applicable in the real world due to the time consumption required.

On that score, a more integrated workflow would be required, both in terms of detailed optical data accessibility and simulation software interoperability, to encourage STPV elements use in the building sector.
To conclude, it would be expected that existing barriers for the introduction of active construction components into the urban fabric will be jointly faced by photovoltaic and building construction industries, as well as by architects and designers, in order to enable BIPV emerging technologies to contribute to the improvement of the building sector sustainability.

\section{References}

[1] Oliver M, Jackson T. Energy and economic evaluation of building-integrated photovoltaics. Energy 2001;26:431-9.

[2] Pagliaro M, Ciriminna R, Palmisano G. BIPV: merging the photovoltaic with the construction industry. Prog Photovolt Res Appl 2010;18:61-72.

[3] Petter Jelle B, Breivik C, Drolsum Røkenes H. Building integrated photovoltaic products: a state-of-the-art review and future research opportunities. Sol Energy Mater Sol Cells 2012;100:69-96.

[4] Ban-Weiss G, Wray C, Delp W, Ly P, Akbari H, Levinson R. Electricity production and cooling energy savings from installation of a building-integrated photovoltaic roof on an office building. Energy Build 2013;56:210-20.

[5] Commission E. Directive 2010/31/EU of the European Parliament and of the Council of 19 May 2010 on the energy performance of buildings. Off J Eur Union 2010;L153:13-35.

[6] Li DHW, Yang L, Lam JC. Zero energy buildings and sustainable development implications - a review. Energy 2013;54:1-10.

[7] Annunziata E, Frey M, Rizzi F. Towards nearly zero-energy buildings: the state-of-art of national regulations in Europe. Energy 2013;57:125-33.

[8] Denton JC, Rakopoulos CD, Tsatsaronis G, Frangopoulos CA, Stegou-Sagia A, Antonopoulos K, et al. The impact of glazing on energy consumption and comfort. Energy Convers Manage 2007;48:2844-52.

[9] Iqbal I, Al-Homoud MS. Parametric analysis of alternative energy conservation measures in an office building in hot and humid climate. Build Environ 2007; $42: 2166-77$.

[10] Hien WN, Liping W, Chandra AN, Pandey AR, Xiaolin W. Effects of double glazed facade on energy consumption, thermal comfort and condensation for a typical office building in Singapore. Energy Build 2005;37:563-72.

[11] Bodart M, De Herde A. Global energy savings in offices buildings by the use of daylighting. Energy Build 2002;34:421-9.

[12] Inanici MN, Demirbilek FN. Thermal performance optimization of building aspect ratio and south window size in five cities having different climatic characteristics of Turkey. Build Environ 2000;35:41-52

[13] Gil-Lopez T, Gimenez-Molina C. Influence of double glazing with a circulating water chamber on the thermal energy savings in buildings. Energy Build 2013;56:56-65.

[14] Chow T, Li C, Lin Z. Innovative solar windows for cooling-demand climate. So Energy Mater Sol Cells 2010;94:212-20.

[15] Chow T-T, Qiu Z, Li C. Potential application of "see-through" solar cells in ventilated glazing in Hong Kong. Sol Energy Mater Sol Cells 2009;93:230-8. 
[16] Olivieri L, Caamaño-Martin E, Olivieri F, Neila J. Integral energy performance characterization of semi-transparent photovoltaic elements for building integration under real operation conditions. Energy Build 2014;68:280-91.

[17] Quesada G, Rousse D, Dutil Y, Badache M, Hallé S. A comprehensive review of solar facades. Transparent and translucent solar facades. Renew Sustain Energy Rev 2012;16:2643-51.

[18] Wong PW, Shimoda Y, Nonaka M, Inoue M, Mizuno M, Semi-transparent PV. Thermal performance, power generation, daylight modelling and energy saving potential in a residential application. Renew Energy 2008:33:1024-36.

[19] Crawley DB, Lawrie LK, Winkelmann FC, Buhl WF, Huang YJ, Pedersen CO et al. EnergyPlus: creating a new-generation building energy simulation program. Energy Build 2001;33:319-31.

[20] Miyazaki T, Akisawa a, Kashiwagi T. Energy savings of office buildings by the use of semi-transparent solar cells for windows. Renew Energy 2005;30:281-304.

[21] Ng PK, Mithraratne N, Kua HW. Energy analysis of semi-transparent BIPV in Singapore buildings. Energy Build 2013;66:274-81.

[22] He W, Zhang YX, Sun W, Hou JX, Jiang QY, Ji J. Experimental and numerical investigation on the performance of amorphous silicon photovoltaics window in East China. Build Environ 2011;46:363-9.

[23] Bahaj AS, James P a B, Jentsch MF. Potential of emerging glazing technologies for highly glazed buildings in hot arid climates. Energy Build 2008;40: $720-31$.

[24] Beckman WA, Broman L, Fiksel A, Klein SA, Lindberg E, Schuler M, et al TRNSYS the most complete solar energy system modeling and simulation software $1994 ; 5$.

[25] Song J-H, An Y-S, Kim S-G, Lee S-J, Yoon J-H, Choung Y-K. Power output analysis of transparent thin-film module in building integrated photovoltaic system (BIPV). Energy Build 2008;40:2067-75.

[26] Peng J, Lu L, Yang H. An experimental study of the thermal performance of a novel photovoltaic double-skin facade in Hong Kong. Sol Energy 2013;97: 293-304.

[27] Park KE, Kang GH, Kim HI, Yu GJ, Kim JT. Analysis of thermal and electrica performance of semi-transparent photovoltaic (PV) module. Energy 2010;35: $2681-7$.

[28] Chen F, Wittkopf SK, Khai Ng P, Du H. Solar heat gain coefficient measurement of semi-transparent photovoltaic modules with indoor calorimetric hot box and solar simulator. Energy Build 2012;53:74-84.

[29] Lu L, Law KM. Overall energy performance of semi-transparent single-glazed photovoltaic (PV) window for a typical office in Hong Kong. Renew Energy 2013;49:250-4.

[30] Real Decreto 314/2006. Código Técnico de la Edificación. Boletín Oficial de Estado, BOE 12/09/13, Madrid, Spain; 2013 [n.d].

[31] Entity, Ecofys GmbH. POLIS - solar urban planning - the National State of the Art in Germany; 2011.

[32] Asdrubali F, Bonaut M, Battisti M, Venegas M. Comparative study of energy regulations for buildings in Italy and Spain. Energy Build 2008;40: $1805-15$.

[33] CENELEC European Committee for Electrotechnical Standardization. Photovoltaics in buildings - DRAFT prEN 50583; 2012. p. 41.

[34] International Glazing Database. http://windowoptics.lbl.gov/data/igdb, [accessed 14.05.14], n.d.
[35] Complex Glazing Database. http://windowoptics.lbl.gov/data/cgdb, [accessed 14.05.14], n.d.

[36] Köppen W. Das geographische system der klimate; 1936. Berlin.

[37] Cerón 1, Caamaño-Martín E, Neila F]. "State-of-the-art" of building integrated photovoltaic products. Renew Energy 2013;58:127-33.

[38] Lyons P, Wong J, Bhandari M. A comparison of window modelling methods in EnergyPlus 4.0. In: Fourth Int Conf IBPSA; 2010. p. 177-84.

[39] E.C.f. Standardization. Glass in building. Determination of thermal transmittance (U value). Calculation method; 2011. EN 673:2011.

[40] E.C.f. Standardization. Glass in building. Determination of luminous and solar characteristics of glazing; 2011. EN 410:2011.

[41] IEA. Solar Energy and architecture methods and tools for solar design report T.41.B.3 solar design of buildings for architects: review of solar design tools; 2012.

[42] Dubois M-C, Blomsterberg Å. Energy saving potential and strategies for electric lighting in future North European, low energy office buildings: a literature review. Energy Build 2011;43:2572-82.

[43] Van Dijk HAL. The European project REVIS, daylighting products with redirecting visual properties. In: Proc NorthSun Conf; 2001.

[44] Van Dijk HAL. Reference office for thermal, solar and lighting calculations. Performance of solar facade components; 2001. IEA-SHC Tak27. Delft, the Netherlands.

[45] Designbuilder - version 3.2.0.073. http://www.designbuilder.co.uk, [accessed 14.05.14], n.d.

[46] Reinhart CF, Wienold J. The daylighting dashboard - a simulation-based design analysis for daylit spaces. Build Environ 2011;46:386-96.

[47] Optics - version 5.1. http://windows.lbl.gov/software/Optics/optics.html, [accessed 14.05.14], n.d.

[48] Window - version 6.3.26.0. http://windows.lbl.gov/software/window/ window.html, [accessed 14.05.14], n.d.

[49] COMFEN - version 4.1.25. http://windows.lbl.gov/software/comfen/comfen. html, [accessed 14.05.14] n.d.

[50] PVsyst - version 5.55. http://www.pvsyst.com, [accessed 14.05.14], n.d.

[51] Photon International solar modules database. http://www.photon.info/ photon_site_db_solarmodule_en.photon, [accessed 14.05.14], n.d.

[52] Photon International solar inverters database. http://www.photon.info/ photon_site db_wechselrichter en.photon, [accessed 14.05.14], n.d.

[53] Pérez-Lombard L, Ortiz J, González R, Maestre IR. A review of benchmarking, rating and labelling concepts within the framework of building energy certification schemes. Energy Build 2009;41:272-8.

[54] Ibn-Mohammed T, Greenough R, Taylor S, Ozawa-Meida L, Acquaye A. Operational vs. embodied emissions in buildings-a review of current trends. Energy Build 2013;66:232-45.

[55] Wienold J Christoffersen I Evaluation methods and development of a new glare prediction model for daylight environments with the use of CCD cameras. Energy Build 2006;38:743-57.

[56] Reinhart C, Selkowitz S, Nabil A, Mardaljevic J. Useful daylight illuminances: a replacement for daylight factors. Energy Build 2006;38:905-13.

[57] Mardaljevic J, Heschong L, Lee E. Daylight metrics and energy savings. Light Res Technol 2009;41:261-83. 